\title{
Direct onion sowing under soil tillage $\operatorname{methods}{ }^{1}$
}

\author{
Lucas Dotto ${ }^{2}$, Alcir José Modolo ${ }^{*}$ (1), Thiago de Oliveira Vargas ${ }^{2}$, Maicon Sgarbossa², \\ Juan Paulo Xavier de Freitas ${ }^{3}$, Luana da Silva Cadore ${ }^{4}$
}

$10.1590 / 0034-737 X 202269010005$

\begin{abstract}
Onion production is conditioned to the adopted techniques during the cultivation. Sowing depth, soil preparation and cultivars are determinant factors for productivity to be increased. Two experiments were developed, the first with the objective of evaluating the effect of sowing depths and soil preparation methods on the germination and development of onion seedlings, while the objective of the second was to evaluate the productivity of onion cultivars as a soil preparation function. In experiment I, the split plot scheme was adopted, where the main plots consisted on soil tillage methods (total area and bed) and in the subplots, the sowing depths $(0.5 ; 1.0 ; 1.5$ and $2.0 \mathrm{~cm}$ ), with six replicates. Experiment II was carried out in a split plot scheme, in which the main plots consisted on soil tillage methods (total area and bed) and in the subplots, such as onion cultivars (Itajubá, Rainha, Salto Grande, Ômega, Mulata and BR29), with four replicates. The $1.5 \mathrm{~cm}$ sowing depth provided greater speed of germination and plant stand. Raising beds offers the best initial seedling development. The onion cultivation under beds offers the highest vegetative development and productivity.
\end{abstract}

Keywords: Allium cepa; emergency speed; productivity; cultivars, sowing depth.

\section{INTRODUCTION}

Onions are among the most consumed foods in the world. In Brazil it stands out alongside potatoes and tomatoes as one of the most economically important vegetables, in which its production in 2018 reached 1,538,499.00 t (IBGE, 2019). In the 2017/18 harvest in Paraná state, about $125,737.55 \mathrm{t}$ of onion were produced, in which the Southwest region participates with $0.8 \%$ of the total production of the state, with an average of $26.06 \mathrm{t} \mathrm{ha}^{-1}$ (SEAB, 2018).

Various techniques are studied in order to increase the crop productivity, among them it can be mentioned the soil preparation, with harrows and raising of beds, as it presents the advantage of eliminating invasive plants, draining excess water and inducing the augmentation of the root system, however, the adoption of this technique has been discussed, due to the damage of the soil (Carva- lho Filho et al., 2007). In this context, the development of production systems that ensure the environment balance and its resources, with the aim of reducing erosion processes caused by soil overturning are extremely important (Tavella et al., 2010).

For the implementation of the culture in the field, the need for a good seedling emergence is also highlighted, where the sowing depth ends up becoming a determining factor, since, when high depths are adopted, there is a downfall in germination and/or uneven stand. At lower depths, the seeds are susceptible to inclement weather such as rain and wind, in addition to encountering difficulties in absorbing water by decreasing the contact surface of the seed with the soil (Santos et al., 2019).

It is also noteworthy the choice of cultivars adapted to the region which favor gradual and constant increases in yield and, at the same time, bring low cost to the

\footnotetext{
Submitted on October $7^{\text {th }}, 2020$ and accepted on March $23^{\text {th }}, 2021$.

${ }^{1}$ This work is part of the first author's Master Dissertation.

2 Universidade Tecnológica Federal do Paraná, Departamento Acadêmico de Ciências Agrárias, Pato Branco, Paraná, Brazil. lucas.dotto3@gmail.com; alcir@utfpr.edu.br; thiagovargas@utfpr.edu.br; maicon_sgarbossa@hotmail.com

${ }^{3}$ Instituto Federal Catarinense, Rio do Sul, Santa Catarina, Brazil. juanagronomia@hotmail.com

${ }^{4}$ Universidade Federal de Santa Maria, Departamento de Fitotecnia, Santa Maria, Rio Grande do Sul, Brazil. luanacadore@ gmail.com

*Corresponding author: alcir@utfpr.edu.br
} 
producer. The use of open pollinated varieties (OPV) can present advantages to rural producers, since when compared to hybrid seeds, similar characteristics end up in the production of the bulbs, in terms of color, diameter and functional characteristics. However, OPV draws attention due to the low cost of seeds and greater plasticity in stress conditions (Ciancaleoni et al., 2014).

Within this context, the objective of this work was to determine the ideal sowing depth for onion cultivation and evaluation of the cultivar performance (OPV) under soil tillage methods.

\section{MATERIAL AND METHODS}

Two experiments were performed, the experiment I has the objective of evaluating the effect of the sowing depths and soil preparation methods on the germination and development of onion seedlings, while the experiment II aimed to evaluate the productivity of onion cultivars in function of soil preparation.

The experiment was carried out in the experimental area of UTFPR - Pato Branco Campus, located at coordinates $26^{\circ} 10^{\prime} 31.2$ ' $\mathrm{S}$ and 52 41'24.2" W. According to Embrapa (2013), the region's soil is classified as dystrophic Red Latosol, with a very clayey texture $(83.0 \%$ clay, $15.4 \%$ silt and $1.6 \%$ sand). The climate is Cfa type, humid subtropical (Alvares et al., 2013).

The experiment was carried out until the seedling emergence stabilized, in a split plot scheme, where the main plots consisted on two soil tillage methods (total area and bed) and in the subplots, four sowing depths $(0.5 ; 1.0 ; 1.5$ and $2.0 \mathrm{~cm})$ in a randomized block design with six replications. Each experimental unit consisted of an area of $9.0 \mathrm{~m}^{2}(1.0 \times 9.0 \mathrm{~m})$.

The soil preparation was made in a total area with a tillage and two leveling harrows and, for the treatments with preparation of beds, the accomplishment of the embedment was added with the aid of a embedded rotary hoe. The beds were $0.2 \mathrm{~m}$ high $\times 1.0 \mathrm{~m}$ wide $\times 9.0 \mathrm{~m}$ long.

Sowing was carried out in simple rows, spaced $0.25 \mathrm{~m}$ apart, using cultivar BR29, with sowing density of 13 seeds $\mathrm{m}^{-1}$. A pneumatic precision seeder for conventional planting, of the Jumil® brand, model "JM NATURA air 2400", with five seeding lines and displacement speed of $1.8 \mathrm{~km} \mathrm{~h}^{-1}$ was used.

To ensure the good development of the onion seedlings, irrigation was carried out when necessary, with the aid of Agropolo® sprinklers, model NY-30, with a pressure of $30 \mathrm{mca}$, a diameter of 31.80 meters range and a flow of $2.66 \mathrm{~m}^{3} \mathrm{~h}^{-1}$.

For the control of invasive plants, Herbadox ${ }^{\circledR}$ (Pendimethalin) was applied at a dose of $3.0 \mathrm{~L} \mathrm{ha}^{-1}$, with a spray volume of $300 \mathrm{~L} \mathrm{ha}^{-1}$, with a costal sprayer at constant pressure $\left(\mathrm{CO}_{2}\right)$, equipped with a 2.0 meter long spout bar.
The seedling emergence speed index (ESI) of $5.0 \mathrm{~m}$ in length was evaluated on the central line of each plot. The count of emerged seedlings was performed daily until the number of seedlings was constant, according to Maguire (1962).

The initial seedling stand was determined when they were about six centimeters high, by counting on the central line in five linear meters of each plot and the values were expressed in seedlings ha ${ }^{-1}$.

After stabilizing the emergency ( 15 days after sowing), 10 samples were collected from each experimental unit, to measure the height of the aerial part. The parts of the seedlings obtained in the stature assessment were transferred to paper bags and these were placed in an oven with forced air circulation at $65^{\circ} \mathrm{C}$, until constant mass. Afterwards, they were weighed on a scale with an accuracy of $0.001 \mathrm{~g}$, the dry matter result was expressed in mass (mg).

The data were submitted to analysis of variance and when there was a significant difference ( $\mathrm{p}$ d" 0.05), additional tests were deployed using the $\mathrm{R}$ software ( $\mathrm{R}$ Core Team, 2018). The normality and homogeneity of the response variables were determined using the ShapiroWilk and Oneillmathews tests, respectively.

Experiment II was developed in a commercial field, in Pato Branco-PR municipality, located at $26^{\circ} 16^{\prime} 12.2^{\prime \prime} \mathrm{S}$ and $52^{\circ} 39^{\prime} 55.5^{\prime \prime} \mathrm{W}$ coordinates in a dystrophic Red Latosol, with clay texture (56\% clay, $25 \%$ clay silt and $19 \%$ sand), with the following chemical characteristics of the top soil $(0-0,20 \mathrm{~m})$ layer: $\mathrm{pH}$ in $\mathrm{CaCl}_{2}=4.8 ; \mathrm{P}($ Mehlich-1) $=34.45$ $\mathrm{mg} \mathrm{dm}{ }^{-3} ; \mathrm{K}, \mathrm{Ca}, \mathrm{Al}=0.83,27,27,0.20 \mathrm{cmolc} \mathrm{dm}^{-3}$, respectively; $\mathrm{CTC}=16.60, \mathrm{~V}=6.63 \%$, and $\mathrm{MO}=46.91 \mathrm{~g}$ $\mathrm{dm}^{-3}$.

The experiment was carried out in a split plot scheme, where the main plots consisted on two soil tillage methods (total area and bed) and in the subplots, six onion cultivars (Itajubá, Rainha, Salto Grande, Omega, Mulata and BR29), in a randomized block design with four replications. Each experimental unit consisted of a $7.0 \mathrm{~m}^{2}$ $(1.0 \times 7.0 \mathrm{~m})$ area.

The sowing depth of $1.5 \mathrm{~cm}$ was used, as it was the one that provided the best seedling development in experiment I. For the soil preparation and sowing, it was used the same methodology described in the first experiment.

For the correction of the soil $\mathrm{pH}$, a simple mineral granular fertilizer of calcium carbonate FORTcálcio ${ }^{\circledR}$ was applied, and for the fertilization of the area, the result of the chemical analysis of the soil was taken into account, making basic application and the fractionation of the covering fertilization in two stages following the recommendations of the manual of fertilization and liming for the state of Paraná (SBCS, 2017). 
For physical characterization of the soil, at the time of harvest, the measurement from resistance to penetration was performed, with the aid of a penetrometer, brand Falker, with a tip (cone) of $1.0 \mathrm{~cm}^{2}$ in area, with ten samples per unit being randomly performed. experimental, whose maximum values observed in the $0.0-0.20 \mathrm{~m}$ layer was 1.89 $\mathrm{MPa}$ in embedded soil and 2.87 MPa for the total area.

For leaf evaluations, 10 bulbs were collected from each experimental unit, when about $20 \%$ of the plants fell. The number of photosynthetically active and fully developed leaves were counted, dry or deteriorated leaves were disregarded (Kurtz et al., 2013).

To evaluate the height of the leaves, a ruler graduated in millimeters was used, measuring the stretched leaves, from the pseudostem to the apex of the highest leaf, the results were expressed in centimeters (Oliveira et al., 2018).

The cycle was calculated by the number of days that comprised the development of the plants, from sowing to tipping. The point of harvest was determined visually when $75 \%$ of the plants in the experimental unit presented a fall over of the aerial part (Santos et al., 2017).

The final plant stand was held prior to the bulb harvest, by counting the plants present in the two central lines of each experimental unit. Subsequently, the bulbs were harvested on the two central lines in two linear meters of each line and left on the ground with the leaves distributed over the bulbs so that they were protected from the sun. After 10 days of cure in the field, the bulbs were removed from the site and sent to the laboratory where subsequent assessments were made.

In the evaluation of the bulb diameter average, 10 bulbs from each experimental unit were measured, where the equatorial diameter was analyzed with the aid of a digital caliper, with the results expressed in millimeters (Oliveira et al., 2018).

The average mass of commercial bulbs was determined by dividing the mass of commercial bulbs (perfect bulbs with a transverse diameter $>50 \mathrm{~mm}$ and $<70 \mathrm{~mm}$ ) by the number of commercial bulbs.

In order to evaluate productivity by class, the bulbs harvested in the two central lines were classified by the largest transverse diameter, according to the Ceagesp (2001) classification. The bulbs were classified as: Class 0 or refuse: $<15 \mathrm{~mm}$; Class 1: 15 to $35 \mathrm{~mm}$; Class 2: 35 to 50 $\mathrm{mm}$; Class 3: 50 to $70 \mathrm{~mm}$; Class 4: 70 to $90 \mathrm{~mm}$, the results were expressed in tons per hectare.

The data were submitted to analysis of variance and when there was a significant difference ( $\mathrm{p} \mathrm{d}$ " 0.05), the complementary tests were deployed using the R software (R Core Team, 2018). The normality and homogeneity of the variables responses were analyzed using the ShapiroWilk and Oneillmathews tests, respectively.

\section{RESULTS AND DISCUSSION}

\section{Experiment I}

The emergency march of the onion crop increased from the twelfth day after sowing and stabilized at the twentythird day. When sown at the depth of $1.5 \mathrm{~cm}$, it resulted in $70.10 \%$ of emergence against $69.10 \%$ for the depth of 1.0 $\mathrm{cm}, 64.10 \%$ for $2.0 \mathrm{~cm}$ and $29.65 \%$ when sown at $0.5 \mathrm{~cm}$ deep (Figure 1A).

Lee et al. (2011) describe that the depth of seed deposition in the soil, affects germination, emergence and plants establishment, through the availability of humidity, temperature and exposure to light. On the other hand, the decrease in emergence as the sowing depth increases, may be related to the fact that greater depths represent a physical barrier imposed by the soil, and because they are small seeds, their reservoires are insufficient for them to appear in greater quantities (Lee et al., 2011).

For the different soil tillage (Figure 1B), it is noted that the tillage with a bed provided a greater response, with $67.07 \%$ against $49.59 \%$ when the crop was sown in total area. This result is related to the size of the aggregates, since when cultivated under a bed the soil undergoes greater disintegration due to the effect of the rotary hoe, improving the soil-seed ratio, thus providing a higher percentage of emergence in relation to the sown in total area.

For the emergence speed index (Figure 1C), when the crop was sown in preparation with a bed, the highest index (27.85) occurred in the depth of $1.34 \mathrm{~cm}$. When sowing the total area, the index of 21.16 was reached when sowing at a depth of $1.87 \mathrm{~cm}$, that is, the preparation of the soil with a bed, resulted in a higher rate of emergence speed with less depth of sowing, when compared to cultivation in total area. This can be explained due to the better soil/ seed relation obtained with the spraying of the soil, provided by the rotary hoe, making it cover most of the seed, providing a higher moisture content to promote germination, initial root growth and elongation of tissues.

This soil/seed relation is described by Carvalho \& Nakagawa (2012), where the authors mention that the greater contact of the seed with the soil, allows the rehydration of its tissues, increasing the respiratory activities and germination, as the water content, aeration, and the availability of oxygen are essential for the germination process of any agricultural specie.

In addition, it is worth highlighting the importance of the ideal sowing depth in the emergence speed of the onion crop. When adopted at very high depths, the seeds are prepared for a longer period of susceptibility to pathogens, the appearance of physical barriers to seedling emergence and reduced expression of seed force. On the other hand, sowing carried out at depths close to the surfaces, predispose the seeds to water or thermal deficit. 
These stresses can reflect on the formation of small and fragile seedlings (Alves et al., 2014).

For the initial seedling stand (Figure 1D) the depth of $1.34 \mathrm{~cm}$ showed a greater increase, resulting in 454,839 seedlings ha ${ }^{-1}$ for soil preparation with embedment. For the sowing in total area, the depth of $1.79 \mathrm{~cm}$ resulted in a maximum stand of 345,366 seedlings ha $^{-1}$.

The knowledge about germination of a given specie is also important for decision making before cultivation. The onion crop has epigeal germination, that is, when the hypocotyl elongates, causing the cotyledons to exceed the soil surface (Cardoso, 2008).

The efforts that the seedlings need to make in the epigeal germination, results in the use of the reserve tissue substances so that the cotyledons are dragged towards the soil surface. This high energy expenditure often affects the emergence of seedlings in the soil, which possibly may have occurred in the preparation of soil in a total area, where due to the presence of larger aggregates, they ended up becoming a physical barrier to the seedlings emergence.

The difficulties that species with epigeal germination encounter in their development at different depths are described by Vazquez et al. (2011), where the aerial part of the seedling develops using the reserved substances that remain after the emergency rotational movement. The tendency is for the height of the seedlings to be smaller, with an increase in the sowing depth.


Figure 1: Onion seedling emergency march according to sowing depths (A) and soil tillage methods (B). Index of emergence speed (C) and initial stand of onion seedlings (D). Height of aerial part of seedlings (E) and dry matter of aerial part of onion seedlings (F) according to sowing depths and soil preparation methods.

Rev. Ceres, Viçosa, v. 69, n.1, p. 031-039, jan/feb, 2022 
For the height of the aerial part of onion seedlings, soil preparation did not influence development. However, the sowing depths showed a significant difference, where the depth of $1.44 \mathrm{~cm}$ provided seedling development with $6.0 \mathrm{~cm}$ height (Figure 1E).

The sowing depth is specific to each species and, when appropriate, provides germination and emergence of uniform seedlings and, when excessive, prevents their emergence in the soil, causing their death before breaking the soil, due to problems related to the physiological quality of the seed, such as attack by insects or microorganisms, physical impediments of the soil or other factors (Almeida et al., 2010).

The soil preparation with bed and total area showed higher production of dry matter in the aerial part at depths of 1.04 and $1.62 \mathrm{~cm}$, respectively. The highest production achieved in the construction site was $5.24 \mathrm{mg}$, while for the total area $4.63 \mathrm{mg}$ (Figure 1F).

The measurement of dry matter of parts of plants, can be related to crop yield, which depends on the production of total biomass and the distribution of dry matter between the productive and non-productive parts of the plant. Brewster (2008) describes that the onion has low dry mass accumulation rates during the early stages of development, followed by rapid growth and finally by a stationary phase whose length varies depending on the cultivar, plant health and climatic conditions. Low leaf dry matter results are also related to bulb productivity. It is important to search for the ideal sowing depth, which leads to good development for the seedling, since the initial responses will continue throughout the cultivation cycle.

\section{Experiment II}

For the variable number of leaves, the cultivar Mulata showed a higher average, but did not differ significantly from the cultivars Salto Grande, Itajubá and Ômega (Table 1). The cultivar Rainha presented the lowest number of leaves, differing statistically from the cultivars Mulata and Salto Grande.

Table 1: Average number of leaves per bulb and average leaf height of onion cultivars

\begin{tabular}{lcc}
\hline Cultivars & $\begin{array}{c}\text { Average number } \\
\text { of leaves }\end{array}$ & $\begin{array}{c}\text { Average leaf } \\
\text { height }(\mathbf{c m})\end{array}$ \\
\hline Mulata & $8.65 \mathrm{a}$ & $56.49 \mathrm{ab}$ \\
Salto Grande & $8.35 \mathrm{ab}$ & $58.05 \mathrm{ab}$ \\
Itajubá & $7.95 \mathrm{abc}$ & $59.19 \mathrm{a}$ \\
Ômega & $7.70 \mathrm{abc}$ & $53.76 \mathrm{~b}$ \\
BR29 & $6.95 \mathrm{bc}$ & $55.36 \mathrm{ab}$ \\
Rainha & $6.80 \mathrm{c}$ & $55.01 \mathrm{ab}$ \\
\hline
\end{tabular}

Averages followed by the same letter, vertically, do not differ by Tukey's test, at a level of 5\% probability of error.
The number of leaves is related to the number of leaf sheaths, in its turn, they have the development influenced by several factors, both intrinsic and extrinsic of each cultivar (Menezes Júnior \& Vieira Neto, 2012).

According to Oliveira et al. (2018), both the height of the plant and the number of leaves, influence the final bulb size. By the fact of the bulb is formed by the accumulation of reserves at the base of the sheath, the greater the photosynthetic area, the greater the accumulation of photoassimilates, resulting in an increase in dry matter (Brewster, 2008).

When analyzing the behavior of leaf height, it is noted that the cultivars Itajubá and Ômega presented statistical difference between them, in which the cultivar Itajubá showed greater leaf development $(59.19 \mathrm{~cm})$, while the cultivar Ômega showed the lowest average among the studied cultivars $(53.76 \mathrm{~cm})$. The other cultivars showed no significant difference, with averages ranging from 55.01 to $58.05 \mathrm{~cm}$.

In the cycle analysis it is noted that only the cultivar Omega showed a significant difference between the soil preparations, and when sown in total area, the cultivar showed a delay of 5.25 days until the tipping of the pseudostem when compared to enbedded soil (Table 2).

Analyzing the cycle between the cultivars studied, it is noted that when preparing soil with a bed, the cultivar Ômega showed the lowest cycle, differing from the other cultivars. But for the cultivation of onion in soil preparation in total area, the cultivars Ômega and Itajubá took less time to develop completely, without differing statistically from each other.

The cycle of cultivars is an important characteristic to be considered when planning to conduct the crop, since the shorter the cycle, the better the use of the soil, allowing the entry of other crops during the year, thus increasing the profitability of the area (Faria et al., 2012).

For the final plant population, there was no significant interaction between cultivars and soil tillage, demonstrating only one significance for the soil tillage factor in isolation, with the highest values obtained in cultivation under beds, with an average of 480,000 bulbs ha $^{-1}$ against 403,333 for the cultivation of onion in total area. The preparation of soil with a tillage and two harrows, plus the embedment practice, provided greater soil spraying and less compaction, thus explaining the response to the larger plant population.

The compaction and presence of soil aggregates ends up becoming a limiting factor in onion production, where seed germination, as it is a fragile and still developing plant organ, may have its emergency compromised when encountering physical barriers, explaining the low final population of bulbs in the cultivation under total area (Alves et al., 2014). Because of the soil aggregates, if they 
constitute physical barriers in the emergence of onion seedlings, Nick \& Borém (2018) describe the need to use a rotary hoe for the destructuring of aggregates. In addition, the use of a rotary hoe to make beds facilitates drainage, increases soil porosity and reduces the incidence of pathogens present there (Carvalho et al., 2007).

In the average bulb diameter, the cultivars Mulata, Ômega, BR29 and Rainha presented larger average bulb diameters, when cultivated under bed soil preparation, without differing statistically from each other (Table 3). On the other hand, when analyzing the cultivation of onion in total area, the cultivars do not show significant difference in the average diameter of bulbs.

It was verified that the cultivars Salto Grande, Itajubá and Ômega maintained a statistically similar development in both soil preparations. When the Mulata, BR29 and Rainha cultivars were analyzed, inferior results were observed in the cultivation under total area. However, the values found are still within the limits that provide the greatest economic return, since bulb diameters greater than $50 \mathrm{~mm}$ are the most demanded by consumers (Castro et al., 2005). This lesser development may be related to the genetic capacity of the cultivar to carry out cell expansion under conditions in which they are found.

For the average bulbs mass, when preparing soil with a bed, it is noted that the cultivars Mulata, BR29 and Rainha, obtained greater results, without differing statistically from cultivar BR29 (Table 3). In the onion cultivation in total area, there was no statistical difference between the cultivars studied. The cultivar Itajubá presented no significant difference between the studied soil tillage, whereas for other cultivars there is a higher average mass yield of bulbs when preparing soil with a bed. The parameter of average bulb mass is similar to the results obtained in the average diameter of bulbs, in which the cultivation of onion under beds, provides greater development for the evaluated parameters.

Costa et al. (2007) describe that onion cultivation should be carried out in soils free from physical impediments so that it favors the good development of roots and bulbs. The embedded soil structure, in addition to presenting greater porosity and lower density, also presents lower barriers, thus, making the bulb to have the possibility to develop and consequently lead to greater mass obtaining.

For the total bulb productivity (Table 4 ), the production of $50.86 \mathrm{t} \mathrm{ha}^{-1}$ is observed when cultivated in a bed, being higher than the national average $\left(28.13 \mathrm{t} \mathrm{ha}^{-1}\right)$ of the state of Paraná (24.93 tha-1) and from the southwest region which is $11.35 \mathrm{t} \mathrm{h}^{-1}$ (IBGE, 2019). This satisfactory productivity can be explained by the technologies applied during the conduct of the work, such as direct seeding, fractional fertilization, irrigation and other cultural treatments carried out carefully, whenever necessary.

Among the cultivars studied, it is noted that the cultivar Rainha had higher productivity with $55.12 \mathrm{t} \mathrm{ha}^{-1}$, without differing statistically from the cultivar Itajubá that produced $47.61 \mathrm{t} \mathrm{ha}^{-1}$, while the lowest bulb productivity was obtained with the cultivar Mulata (32.29 $\mathrm{t} \mathrm{ha}^{-1}$ ) (Table 4).

The high productivity of the cultivar Rainha may be linked to the edaphic conditions of the region, showing that the choice of the onion variety is dependent on factors such as photoperiod and temperature, and each cultivar

Table 2: Average cycle of onion cultivars (days until tipping) according to soil preparation

\begin{tabular}{lcccccc}
\hline \multirow{2}{*}{$\begin{array}{l}\text { Soil } \\
\text { preparation }\end{array}$} & Salto Grande & Itajubá & Mulata & Ômega & BR29 & Rainha \\
\cline { 2 - 6 } & $167.25 \mathrm{Ca}$ & $157.75 \mathrm{Da}$ & $165.75 \mathrm{Ca}$ & $152.50 \mathrm{~Eb}$ & $179.25 \mathrm{Aa}$ & $175.25 \mathrm{Ba}$ \\
Bed & $167.25 \mathrm{Ca}$ & $157.75 \mathrm{Da}$ & $165.75 \mathrm{Ca}$ & $157.75 \mathrm{Da}$ & $178.75 \mathrm{Aa}$ & $177.75 \mathrm{Ba}$ \\
\hline Total area & &
\end{tabular}

Average followed by the same uppercase letter horizontally, and lowercase letters vertically, without differing by the Tukey test, at a level of $5 \%$ probability of error.

Table 3: Average bulb diameter and average bulb mass in function of soil preparation and onion cultivars

\begin{tabular}{|c|c|c|c|c|c|c|}
\hline \multirow{2}{*}{$\begin{array}{l}\text { Soil } \\
\text { preparation }\end{array}$} & \multicolumn{6}{|c|}{ Average bulb diameter (mm) } \\
\hline & Salto Grande & Itajubá & Mulata & Ômega & BR29 & Rainha \\
\hline$\overline{B e d}$ & $59.78 \mathrm{Ba}$ & $59.18 \mathrm{Ba}$ & $60.10 \mathrm{Aa}$ & $59.74 \mathrm{ABa}$ & $63.13 \mathrm{Aa}$ & $64.23 \mathrm{Aa}$ \\
\hline \multirow[t]{2}{*}{ Total area } & $57.86 \mathrm{Aa}$ & $58.36 \mathrm{Aa}$ & $56.51 \mathrm{Ab}$ & $57.31 \mathrm{Aa}$ & $55.66 \mathrm{Ab}$ & $58.13 \mathrm{Ab}$ \\
\hline & \multicolumn{6}{|c|}{ Average bulb mass (g) } \\
\hline$\overline{\text { Bed }}$ & $92.48 \mathrm{Ba}$ & $91.19 \mathrm{Ba}$ & $108.55 \mathrm{Aa}$ & $91.90 \mathrm{Ba}$ & $102.14 \mathrm{ABa}$ & $117.84 \mathrm{Aa}$ \\
\hline Total area & $70.13 \mathrm{Ab}$ & $76.87 \mathrm{Aa}$ & $62.99 \mathrm{Ab}$ & $61.54 \mathrm{Ab}$ & $60.36 \mathrm{Ab}$ & $80.61 \mathrm{Ab}$ \\
\hline
\end{tabular}

Average followed by the same uppercase letter horizontally and lowercase letters vertically, without differing by the Tukey test, at a level of $5 \%$ probability of error.

Rev. Ceres, Viçosa, v. 69, n.1, p. 031-039, jan/feb, 2022 
has its genotypic characteristics, specific to each producing region, which are necessary for its full development and production of bulbs (Menezes Junior \& Vieira Neto, 2012).

For the total productivity of bulbs class 2 (Table 5), the onion cultivation under bed presented higher averages when compared to the total area. When analyzing the soil preparation with a bed, it is noted that there was no statistical difference between the cultivars analyzed. As for the onion cultivation under total area, the cultivars Ômega, BR29 and Rainha had the highest average of bulbs in class 2 , respectively.

The cultivars Ômega, BR29 and Rainha showed no statistical difference between the soil tillage methods. However, the cultivars Salto Grande, Itajubá and Mulata had higher performance in cultivation under embedded soil. Epagri (2016) describes that the cultivation systems adopted for the production of onion, lead to a different development of the bulbs, influencing both the length and diameter of the bulb and its production.

For the productivity of class 3 bulbs (Table 5), it is noted that the Mulata cultivar was the only one to present a statistical difference between the soil preparation, which when cultivated under a bed it presented greater

Table 4: Total onion bulb productivity as a function of soil preparation

\begin{tabular}{lc}
\hline $\begin{array}{l}\text { Soil } \\
\text { preparation }\end{array}$ & $\begin{array}{c}\text { Total onion bulb } \\
\text { productivity }\left(\mathbf{t ~ h a}^{-1}\right)\end{array}$ \\
\hline Bed & $50.86 \mathrm{~A}$ \\
Total area & $39.23 \mathrm{~B}$ \\
\hline Cultivars & \\
\hline Mulata & $32.39 \mathrm{C}$ \\
Salto Grande & $45.67 \mathrm{~B}$ \\
Itajubá & $47.61 \mathrm{AB}$ \\
Ômega & $43.31 \mathrm{~B}$ \\
Br29 & $46.19 \mathrm{~B}$ \\
Rainha & $55.12 \mathrm{~A}$ \\
\hline
\end{tabular}

Averages followed by the same uppercase letter horizontally and lowercase letters vertically, do not differ by the Tukey test, at a level of $5 \%$ probability of error. productivity with $37.04 \mathrm{t} \mathrm{ha}^{-1}$. Regarding cultivars, it is noted that in cultivation under a bed, there was no statistical difference between them, with average values ranging from 30.15 to $40.02 \mathrm{t} \mathrm{ha}^{-1}$. However, when analyzing the cultivation under total area, cultivar Rainha obtained a higher average, however it did not differ statistically from cultivar BR29.

The bulbs production with a diameter between 50 and $70 \mathrm{~mm}$ (class 3), is the most preferred by the consumer market, which consequently reaches higher market prices (Vidigal et al., 2010). The importance of the bulb classes is also demonstrated by Menezes Júnior \& Vieira Neto (2012), where they describe that the price paid to the producer is related to the productivity of a certain class, in which bulbs with caliber from 35 to $50 \mathrm{~mm}$ (class 2) cost half the price of higher classes bulbs with a transverse diameter greater than $50 \mathrm{~mm}$ (class 3), highlighting thus the importance of obtaining class 3 bulbs, for greater profitability of the producer (Menezes Júnior \& Kurtz, 2016).

The determination of the cultivation system in the root development of the onion is extremely important, as the soil preparation promotes accented soil loss and nutrients, which may reduce the productive capacity of the soil. However, not turning over the soil and the traffic of implements can promote its densification in the superficial layer, in relation to the conventional cultivation, manifested by the increase in the soil density, decrease in the macroporosity and aeration porosity (Gozubuyuk et al., 2014). Attached to this, the presence of aggregates can be considered a limiting factor, which can restrict the growth of the bulbs, leading to morphological changes in diameter and a decrease in length, making them tortuous.

\section{CONCLUSIONS}

The sowing depth of $1.5 \mathrm{~cm}$ stands out as being the most favorable onion cultivation, resulting in higher rates of germination speed and plant stand. For soil preparation, raising beds provides better initial development of onion seedlings.

Table 5: Total productivity of bulbs class 2 and class 3 as a function of soil preparation and onion cultivars

\begin{tabular}{|c|c|c|c|c|c|c|}
\hline \multirow{2}{*}{$\begin{array}{l}\text { Soil } \\
\text { preparation }\end{array}$} & \multicolumn{6}{|c|}{ Total productivity of bulbs class $2\left(\mathrm{t} \mathrm{ha}^{-1}\right)$} \\
\hline & Salto Grande & Itajubá & Mulata & Ômega & BR29 & Rainha \\
\hline Bed & $8.63 \mathrm{Aa}$ & $7.94 \mathrm{Aa}$ & $7.64 \mathrm{Aa}$ & $8.52 \mathrm{Aa}$ & $8.08 \mathrm{Aa}$ & $7.45 \mathrm{Aa}$ \\
\hline \multirow[t]{2}{*}{ Total area } & $4.94 \mathrm{Bb}$ & $4.45 \mathrm{Bb}$ & $4.38 \mathrm{Bb}$ & $7.49 \mathrm{Aa}$ & $7.99 \mathrm{Aa}$ & $6.22 \mathrm{ABa}$ \\
\hline & \multicolumn{6}{|c|}{ Total productivity of bulbs class $3\left(\mathrm{t} \mathrm{ha}^{-1}\right)$} \\
\hline Bed & $37.11 \mathrm{Aa}$ & $33.89 \mathrm{Aa}$ & $37.04 \mathrm{Aa}$ & $31.13 \mathrm{Aa}$ & $30.15 \mathrm{Aa}$ & $40.02 \mathrm{Aa}$ \\
\hline Total area & $33.73 \mathrm{Ba}$ & $31.58 \mathrm{BCa}$ & $21.42 \mathrm{Cb}$ & $30.90 \mathrm{BCa}$ & $36.68 \mathrm{ABa}$ & $45.55 \mathrm{Aa}$ \\
\hline
\end{tabular}

Averages followed by the same uppercase letter horizontally and lowercase letters vertically, do not differ by the Tukey test, at a level of $5 \%$ probability of error. 
The Rainha cultivar presented better performance in the parameters of productivity. In relation to soil preparation, the onion cultivation under beds provides greater vegetative development and yields of productivity.

For onion cultivation under total area, it is possible to indicate the use of cultivars BR29 and Rainha, because for the class 3 bulbs productivity, the most acceptable class for the consumer market, they did not show any difference among the studied soil preparations.

\section{ACKNOWLEDGEMENTS, FINANCIAL SUPPORT AND FULL DISCLOSURE}

The authors are indebted to the Coordenação de Aperfeiçoamento de Pessoal de Nível Superior (Capes), for a scholarship.

Authors declare there is no conflict of interests in carrying the research and publishing this manuscript.

\section{REFERENCES}

Almeida MAS, Melo B, Silva CA, Santana DG \& Silva CJ (2010) Massa de sementes e profundidades de semeadura no desenvolvimento de mudas de tamarindeiro. Revista Brasileira de Fruticultura, 32:591-598.

Alvares CA, Stape JL, Sentelhas PC, Gonçalves JLM \& Sparovek G (2013) Köppen's climate classification map for Brazil. Meteorologische Zeitschrift, 22:711-728.

Alves MM, Alves EU, Silva-Moura SS, Araújo LR, Silva RS \& Ursulino MM (2014) Emergência e crescimento inicial de plântulas de Platymiscium floribundum Vog. em função de diferentes posições e profundidades de semeadura. Ciência Rural, 44:2129-2135.

Brewster JL (2008) Onions and Other Vegetable Alliums. Wallingford, CAB International. 432p.

Cardoso VJM (2008) Germinação. In: Kerbauy GB (Ed.) Fisiologia Vegetal. Rio de Janeiro, Guanabara Koogan. p.384-408.

Carvalho Filho A, Centurion JF, Silva RP, Furlani CEA \& Carvalho LCC (2007) Métodos de preparo do solo: alterações na rugosidade do solo. Engenharia Agrícola, 27:229-237.

Carvalho LCC, Bezerra FML \& Carvalho MAR (2007) Evapotranspiração e coeficientes de cultivo da melancia sem sementes. Revista Ciência Agronômica, 39:53-59.

Carvalho NM \& Nakagawa J (2012) Sementes: ciência, tecnologia e produção. $5^{\text {th }}$ ed. Jaboticabal, FUNEP. 590p.

Castro CM, Almeida DL, Ribeiro RLD \& Carvalho JF (2005) Plantio direto, adubação verde e suplementação com esterco de aves na produção orgânica de berinjela. Pesquisa Agropecuária Brasileira, 40:495-502.

CEAGESP - Companhia de entrepostos e armazéns gerais do estado de São Paulo (2001) Programa Brasileiro para a Modernização da Agricultura: Classificação da Cebola. São Paulo, CEAGESP. 2p.

Ciancaleoni S, Chiarenza GL, Raggi L, Branca F \& Negri V (2014) Diversity characterization of broccoli (Brassica oleracea L. var. itálica Plenck) landraces for their on- farm (in situ) safeguard and use in breeding programs. Genetic resources and crop evolution, 61:451-464.

Costa ND, Cunha TJF \& Rezende GM (2007) Solos e plantio. Available at: http://www.embrapa.br/en/semiarido/sistema_producao. Accessed on: December 15 ${ }^{\text {th }}, 2018$.
Embrapa - Empresa Brasileira de Pesquisa Agropecuária (2013) Sistema brasileiro de classificação de solos. $3^{\text {rd }}$ ed. Brasília, Embrapa. 353p.

EPAGRI - Empresa de Pesquisa Agropecuária e Extensão Rural de Santa Catarina (2016) Manual de boas práticas agrícolas. Available at: http://ciram.epagri.sc.gov.br/ciram_arquivos/arquivos/cebola/acervo/livro_boas_praticas_cebola.pdf. Accessed on: December $1^{\text {st }}, 2019$.

Faria MV, Morales RGF, Resende JTV, Zanin DS, Menezes CB \& Kobori RF (2012) Desempenho agronômico e heterose de genótipos de cebola. Horticultura Brasileira, 30:220-225.

Gozubuyuk Z, Sahin U, Ozturk I, Celik A \& Adiguzel MC (2014) Tillage effects on certain physical and hydraulic properties of a loamy soil under a crop rotation in a semi-arid region with a cool climate. Catena, 118:195-205.

IBGE - Instituto Brasileiro de Geografia e Estatística (2019) Levantamento sistemático de produção agrícola/fevereiro. Available at: https://www.ibge.gov.br/estatisticas/economicas/ agricultura-e-pecuaria/9201-levantamento-sistematico-daproducao-agricola.html $?=\& \mathrm{t}=$ downloads. Accessed on: September $10^{\text {th }}, 2019$.

Kurtz C, Ernani PR, Pauletti V, Menezes Junior FOG \& Vieira Neto J (2013) Produtividade e conservação de cebola afetadas pela adubação nitrogenada no sistema plantio direto. Horticultura Brasileira, 31:559-567.

Lee J, Chauhan BS \& Johnson DE (2011) Germination of fresh horse purslane (Trianthema portulacastrum) seeds in response to different environmental factors. Weed Science, 59:495499.

Maguire JD (1962) Speed of germination-aid in selection and evaluation for seedling emergence and vigor. Crop Science, 2:176-177.

Menezes Júnior FOG \& Vieira Neto J (2012) Produção da cebola em função da densidade de plantas. Horticultura Brasileira, 30:733-739.

Menezes Junior FOG \& Kurtz C (2016) Produtividade da cebola fertirrigada sob diferentes doses de nitrogênio e densidades populacionais. Horticultura Brasileira, 34:571-579.

Nick C \& Borém A (2018) Cebola: do plantio à colheita. $1^{\text {st }}$ ed. Viçosa, UFV. 216p.

Oliveira MG, Dias RC, Melo CAD, Mendes KF, Silva PV, Silva DV \& Reis MR (2018) Tolerância da cebola implantada por semeadura direta ao flumioxazin aplicado em pós-emergência inicial. Revista Brasileira de Herbicidas, 17:585-592.

R Development Core Team (2018) R: A language and environment for statistical computing. Vienna, R Foundation for Statistical Computing. Available at: http://www.r-project.org. . Accessed on: December $15^{\text {th }}, 2019$.

Santos AF, Oliveira MF, Junqueira PD, Correa LN \& Silva RP (2019) Tratamento de sementes de milho com zinco semeadas em diferentes profundidades. Revista Engenharia na Agricultura, 27:111-121.

Santos JOM, Zera FS, Pulici E \& Machado CMM (2017) Efeito da adubação foliar na produtividade e na classificação de diâmetro da cebola. Nucleus, 14:189-216.

SBCS - Sociedade Brasileira de Ciência do Solo. Núcleo Estadual Paraná (2017) Manual de adubação e calagem para o Estado do Paraná. $2^{\text {nd }}$ ed. Curitiba, SBCS/NEPAR. 289p.

SEAB - Secretaria da Agricultura e do Abastecimento (2018) Available at: http://www.agricultura.pr.gov.br/deral/ProducaoAnual. Accessed on: June $21^{\text {th }}, 2019$. 
Tavella LB, Galvão RO, Ferreira RLF, Araujo Neto SE \& Negreiros JRS (2010) Cultivo orgânico de coentro em plantio direto utilizando cobertura viva e morta adubado com composto. Revista Ciência Agronômica, 41:614-618.

Vazquez GH, Souza WJO, Vanzela LS, Isa KM \& Assis AV (2011) Interferência do tipo de germinação - hipógeo ou epígeo no estabelecimento inicial de plântulas em diferentes profundidades de semeadura. Revista Brasileira de Engenharia de Biossistemas, 5:158-169.
Vidigal SM, Moreira MA \& Pereira PRG (2010) Crescimento e absorção de nutrientes pela planta cebola cultivada no verão por semeadura direta e por transplantio de mudas. Bioscience Journal, 26:59-70. 